\title{
HISTORY AND HERITAGE: EXAMINING THEIR INTERPLAY IN INDIA
}

\author{
Swetabja Mallik \\ Department of Ancient Indian History and Culture, University of Calcutta, India
}

\begin{abstract}
The study of history tends to get complex day by day. History and Heritage serves as a country's identity and are inextricable from each other. Simply speaking, while 'history' concerns itself with the study of past events of humans; 'heritage' refers to the traditions and buildings inherited by us from the remote past. However, they are not as simple as it seems to be. The question on historical consciousness and subsequently the preservation of heritage, intangible or living, remains a critical issue. There has always remained a major gap between the historians or professional academics on one hand, and the general public on the other hand regarding the understanding of history and importance of heritage structures. This paper tends to examine the nature of laws passed in Indian history right from the Treasure Trove Act of 1878 till AMASR Amendment Bill of 2017 and its effects with respect to heritage management. It also analyses the sites of Sanchi, Bodh Gaya, and Bharhut Stupa in this context. Moreover, the need and role of the museums has to be considered. The truth lies in the fact that artefacts and traditions both display 'connected histories'; and that the workings of archaeology, history, and heritage studies together is responsible for the continuing dialogue between past, present, and future.
\end{abstract}

Keywords: history, heritage, identity, artefacts, museum, historiography

\section{Introduction}

"Man, who desires to know everything, desires to know himself. Nor is he only one (even if, to himself, perhaps the most interesting) among the things he desires to know. Without some knowledge of himself, his knowledge of other things is imperfect: for to know something without knowing that one knows it is only a half-knowing, and to know that one knows is to know oneself. Self-knowledge is desirable and important to man, not only for its own sake, but as a condition without which no other knowledge can be critically justified and securely based." (Collingwood 1994, p. 205)

History and Heritage are two different terms with different meanings and connotations. The Oxford English Dictionary defines history as "the study of past events" and heritage as "valued things such as historic buildings, passed down from previous generations". These are simple definitions. Historians have varied explanations. For instance, Bloch said, "The word 'history' is very old -so old that men have sometimes grown weary of it" (Bloch 2017). Collingwood viewed it as "special form of thought". Murphey noted history to be a discipline "which seeks to establish true statements about events which have occurred and objects which have existed in the past" (Murphey, 1973). Concerning heritage, a well attempted definition has been recently attempted - "The term heritage is currently used to express key concepts of contemporary society, and it has a multiplicity of meanings that are as different as disciplines in which the term is used i.e., from economics to jurisprudence, from social sciences to historical ones, from engineering to territory, landscape, and architectural sciences" (Selicato, 2016). The classic differentiation was provided by Lowenthal - "History and heritage transmit different things to different audiences. History tells all who will listen what has happened and how things came to be as they are. Heritage passes on exclusive myths of origin and continuance, endowing a select group with prestige and common purpose. History is enlarged by being disseminated; heritage is diminished and despoiled by export" (Lowenthal, 1998, p. 128).

The most interesting interplay of history and heritage occurs in India, the nation with diversified peoples, languages, foods, cultures, and what not. Different aspects like historical scholarship, historical consciousness, 
legislations and heritage conservation, role of museums and artefacts will be considered in showing how both history and heritage helps in understanding clearly our past in present, and how this contextualizes the much critical dimension of identity question for the nation and its citizens in the contemporary society.

\section{Historical Scholarship}

The discussion of historiography is important as it "becomes a prelude to understanding history as a form of knowledge" (Thapar, 2003). The study of history is getting more and more complex as the day progresses and this is obviously ineluctable. Studies are being conducted not only at the macro-level but also at the micro-level, indeed with more emphasis, in order to understand crucial historical phenomena. Herodotus (484-425 BCE) and Ranke (1795-1886) are distinguished and exceptional historians, both of whom enjoy a significant position till date. The former is regarded as the "Father of History" and the modern day stage was set by Leopold von Ranke in the 19th century with his remark on the historian's task- "wie es eigentlich gewesen", i.e. "simply to show how it really was'. Later on, especially in the 20th century, eminent historians and outstanding scholars in their own right like Robin George Collingwood, Edward Hallett Carr, Arnold Joseph Toynbee, Marc Bloch, Geoffrey Barraclough, Eric Hobsbawm et.al contributed vastly to our understanding of history from different perspectives, and have laid a solid foundation to what may be called as the 'theory of history'. For example, Collingwood largely dealt with the philosophy of history and the early Graeco-Roman and Christian historiography right up to modern scientific history writing whereas Carr, on the other hand, wrote his famous What is History? (1961), where he reflected on some critical issues of his own profession. Toynbee devoted his energy and time on his monumental A Study of History in twelve volumes (1934-61), conceived to trace the history of nineteen world civilizations right from their genesis to their disintegration.

Shifting the focus on Indian historiography, it must be noted that there were mainly three schools of thought in pre-independent India - Imperialist, Nationalist, and Marxist. The Imperialist tradition characterizes the writings of British officers, diplomats, and judges mainly alongside with the historians who showed proclivity to write the history from the perspective of the 'colonizers' or 'victors'. James Mill's History of British India (1817) in three volumes marked a new era in Indian historiography as a whole. This was followed on by the works of Vincent Arthur Smith, Frederick Eden Pargiter, Percival Spear, William Wilson Hunter and many more. It must be noted here that the foundation of the Asiatic Society of Bengal in 1784 in Calcutta by Sir William Jones, philologist and orientalist may be regarded as the first institution to not only produce multifarious writings on India but also concerned itself by translating sacred Indian texts, much earlier than that of Mill. "To rule and to learn” and then “compare Orient with Occident” were Jones' major goals (Said 2001).

The Nationalist writings gained impetus as a result of 'nationalist consciousness', and was meant to form an alternative narrative or discourse. It can be said that the school emerged as a response to British projection of India. The most prominent of the voices was that of a middle-class Bengali urging Indians to write their own history was Bankimchandra Chattopadhyay in his Bangadarshan of 1880 (Guha 1988). Romesh Chunder Dutt, Rajendralala Mitra, Ramkrishna Gopal Bhandarkar, Ramesh Chandra Majumdar, Radha Kumud Mookerji, Hem Chandra Raychaudhuri, to name a few who were associated with such writings. They tended to look at Indian past with rational enquiry, though later on critics could point to their nationalist bias. However, in their defense it might be said that they were the products of their age, and the works they produced should be understood in the backdrop of the full-fledged Indian freedom struggle.

The origin of Marxist historiography may be traced to that of Manabendra Nath Roy (1887-1954), an Indian revolutionary and radical activist who was associated with the Communist Party of India and Socialist Workers Party of Mexico, and whose works like India in Transition (1922) and The Future of Indian Politics (1926) set the initial stage. Mention may also be made of Rajani Palme Dutt's India Today (1940). After Indian independence in 1947, the writings of Damodar Dharmanand Kosambi, specially his acclaimed work An Introduction to the Study of Indian History (1956) and The Culture and Civilisation of Ancient India in 
Historical Outline (1964) heralded a new dawn in Indian historiography. In his 1956 classic, Kosambi for the first time introduced concepts like 'feudalism from above' and 'feudalism from below', and modelled his work on Marxian methodology. The progression of history on the basis of the modes of production and man's relation to it proved to be the ideal basis as well as formed the central hypotheses. Marxist historical writings were characterized by materialistic interpretation, understanding and analysis of historical phenomena deriving the ideology from Karl Marx's historical philosophy. Renowned historians like Ram Sharan Sharma, Dwijendra Narayan Jha, Romila Thapar, Irfan Habib among others are the most prominent torch-bearers of this School.

Other than these three main schools of thoughts asserting their dominance in the Indian historiography, there also has been a prominent presence of Subaltern Studies group since the 1980s. It is generally well known that the term 'subaltern' was originally applied by Italian philosopher Antonio Gramsci (1891-1937) in his Prison Notebooks, written between 1929 and 1935. In India it was largely due to the efforts of historian Ranajit Guha that 'Subaltern Studies' as a distinct discipline emerged. It concerned itself with the history of lower class people and the marginalized sections who were perceived to be generally 'voiceless' throughout history and were victims of oppresssion. Guha was the founding editor of Subaltern Studies:Writing on South Asian History and Society, the first volume of which appeared in 1982. Here he criticized the nationalists in presenting the history of the elites and not those people who made contributions on their own to the development of nationalism. Dipesh Chakrabarty, Gayatri Chakravorty Spivak, Gautam Bhadra, Gyanendra Pandey et.al are associated with this school.

While the Imperialist historiography mainly concerned itself with the ancient and medieval history of India, the Nationalist and Marxist schools also focused on the modern history in addition. The Subaltern discourse reflects upon diverse and multi-faceted aspects of modern history. Generally, the writings of Imperialist and Nationalist historians were characterized by their excessive reliability on literary sources. Archaeological sources came to be used much later although many breakthroughs have been attained with the establishment of Archaeological Survey of India in 1871. All these schools of thought shaped, constructed and reconstructed Indian history to a great extent, thereby helping in the understanding of its discrete elements. It would therefore not be an exaggeration to suggest that these schools in themselves constitute a heritage in modern Indian thought. The Nationalists, Marxists, and the Subalterns amply demonstrated that India did have a history of her own and not 'mere episodes', as had been the sneer of Imperialists. 


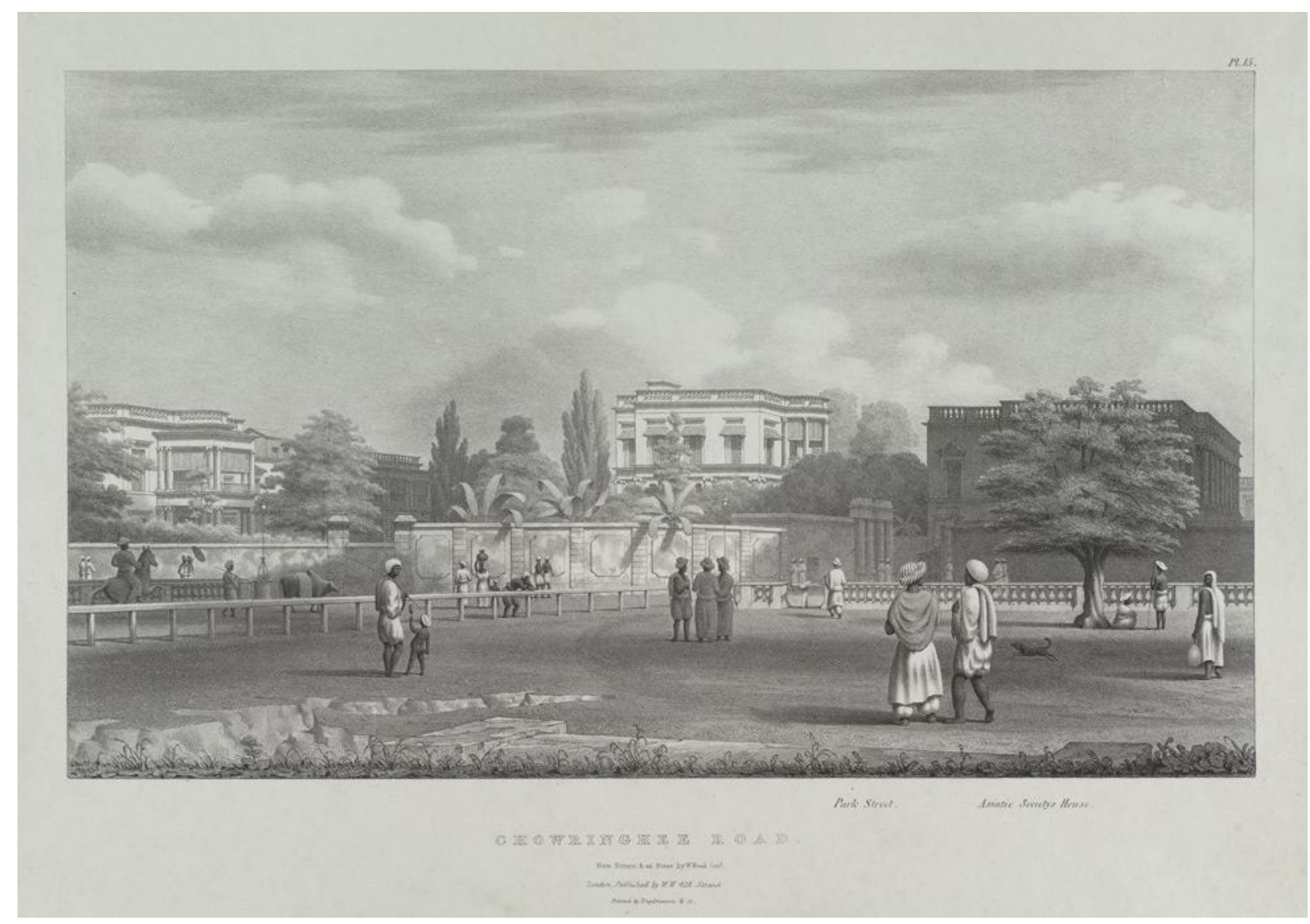

Figure 1: Asiatic Society of Bengal building at the junction of the Park Street, Calcutta in 1833. This is actually a lithograph derived from Plate 15 of the 'Views of Calcutta', an album of paintings by William Wood (1774-1857).

\section{Historical Consciousness and Heritage Conservation}

"The academic historian is often too comfortable in the archives reading through documents from the past and interpreting them for fellow historians. There have not been too many attempts on their part to engage the public in historical questions." (Chowdhury 2017, p.15)

Now, a major question which probably hasn't been adequately addressed is the relation between historical consciousness and heritage conservation. The public tends to play a crucial but invisible role which we tend to undermine. The consciousness of a country's past do not lie only in the hands of the educated intelligentsia in general, or with professional historians and research scholars, but it lies to a great extent and is determined by the general public. For instance, the space of a museum, local or national, and the space of an artefact in the concerned museum is created for the purpose of bestowing knowledge to the public. To be precise, historical knowledge will create awareness among them regarding their past. Why should we preserve a certain building? Why is there a need to maintain this site? These are simple questions but they do have critical aspects. Whenever such question arises, it leads us to think on manifold aspects related with the structure. The structures do speak in volumes of our past, just like a coin. Heritage management and their preservation can only be understood when individuals do have consciousness of their own history. The Babri Masjid-Ram Mandir dispute in Ayodhya amply demonstrates why consciousness with regard to our heritage is absolutely necessary. David Lowenthal correctly observed that historical awareness may demand 'more maturity' than adults ever attain.

According to UNESCO list of Intangible and Tangible heritage, India has thirteen in the former category and a total of thirty-seven (twenty nine cultural, seven natural, one mixed) in the later. Ramlila, Tradition of vedic 
Chanting, Kutiyattam -Sanskrit Theatre were the first entrants in the Intangible heritage category in 2008 and Kumbh Mela being the latest entrant in 2017. Out of twenty-nine cultural tangible heritages the Buddhist monuments at Sanchi (Year of Notification -1989) and Mahabodhi Temple Complex at Bodh Gaya (Year of Notification -2002) prominently feature along with others like Ajanta caves, Elephanta caves, Ellora caves, Agra fort, Konarak Sun Temple, Khajuraho group of monuments etc.

The Indian government has taken legislative measures with respect to the issue of heritage conservation and management, both when it was a colony and when it became independent. The first such step was in the form of The Indian Treasure Trove Act (1878), which states that whenever any treasure exceeding in value of ten rupees is found, the finder shall, as soon as practicable give to the Collector notice in writing -a) of the nature and amount or approximate value of such treasure; b)of the place in which it was found; c) of the date of the finding; and either deposit the treasure in the nearest Government Treasury, or give the Collector such security as the Collector thinks fit to produce the treasure at such time and place as may from time to time require.

Many such legislations of diverse nature were to follow. The Ancient Monuments Preservation Act (1904) provided for the preservation of ancient monuments and of objects of archaeological, historical, or artistic interest. The definition of ancient monument was also given. The Antiquities Export Control Act (1947) provided for controlling the export of objects of antiquarian or historical significance. The Ancient Monuments and Archaeological Sites and Remains Act [AMASR] (1958) led to the preservation of ancient and historical monuments and archaeological sites and remains of national importance. The Antiquities and Art Treasures Act (1972) was enacted for effective control over the moveable cultural property, generally antiquities and art treasures. The AMASR Amendment Bill (2017) which would allow the government to take up infrastructure projects within hundred metre prohibited zones around protected monuments based on the recommendations of National Monuments Authority, generated lot of debate and opposition from the historians. The Bill was passed by the Lok Sabha on January 3. Eminent historian Romila Thapar commented to a leading newspaper- "You cannot talk about conserving ancient heritage and culture and then frame laws that go against their very preservation. A historical monument has to be conserved by leaving enough space around it; otherwise the monument itself may decay once you allow buildings to come up next to it. If you want people to appreciate the monument you should allow visitors to associate it with its neighbourhood by leaving space around the structure." (Venkat 2018)

Three vivid examples of India's heritages may be presented briefly which are world renowned and this would help to understand the context of conservation works undertaken by the British colonizers. These are Bodh Gaya of Bihar, Sanchi Stupa of Madhya Pradesh, and Bharhut Stupa of Madhya Pradesh which now adores the space of Indian Museum of Kolkata, West Bengal.

Alexander Cunningham who visited the Bodh Gaya in 1861 had recommended immediate excavation of the area around the temple. This assignment was entrusted to Major Mead. Mead in a letter to Cunningham wrote about the findings of hundreds of stupas during the course of the excavations. The arches of Bodh Gaya Temple caused dispute between two groups of scholars -Cunningham and Rajendralala Mitra, who viewed the arch as pre-seventh century construction and henceforth concluded that this proved that Hindus knew the construction of the arch. On the other hand, James Fergusson believed the arches to be later creation and that Hindu architecture was characterized by absence of arch. In 1877 three Burmese gentlemen, sent by the king of Burma Mindon Min, to repair the temple arrived and proceeded to work after due permission. However, they extensively damaged the site by clearing away a large area around the shrine, demolishing Ashokan rail and pavement, replastered the interior and what not. They were finally requested to leave and Government of Bengal undertook the repairing task.

In 1880 archaeologist Joseph David Beglar was appointed by Sir Ashley Eden, lieutenant governor of Bengal to supervise the repair of the temple. Beglar's work yielded fruitful results. The vestiges of an older Ashokan 
temple, fragments of railings, and the old vajrasana throne were "dramatic discoveries" (Singh 2004). The restoration work came under huge criticism from Fergusson who had opined that the temple was rebuilt and most of its ancient features were obliterated. James Burgess was severely critical of Beglar and later on British civil servant Sir Henry Cole too expressed his regrets. Only Cunningham came to Beglar's rescue by justifying the restoration work undertaken. Keeping all such confrontations aside, it must be noted that the restoration of Mahabodhi temple was both initiated and completed within Cunningham's tenure as Director General of Archaeological Survey of India. However, a newer dispute over the custodianship of the shrine between the Hindus and the Buddhists arose. After independence, the Indian government's role, the further undertaking of conservation measures and the transformation of Bodh Gaya after its World Heritage status have been attempted at recently (Geary 2018).

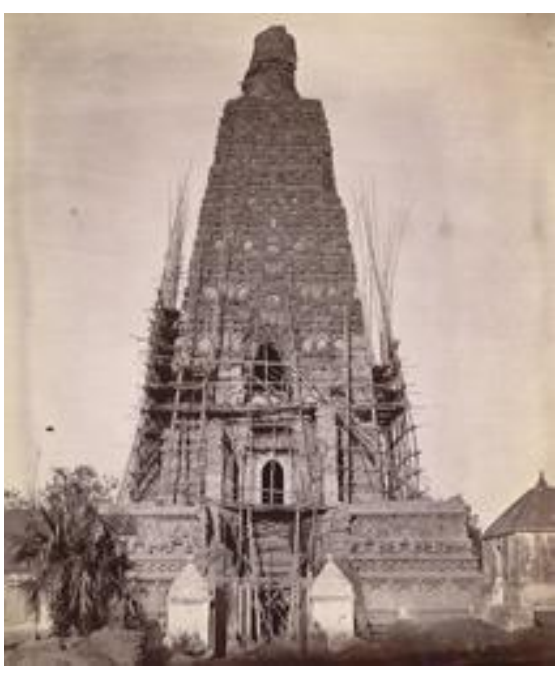

Figure 2: The east façade of the Mahabodhi temple is

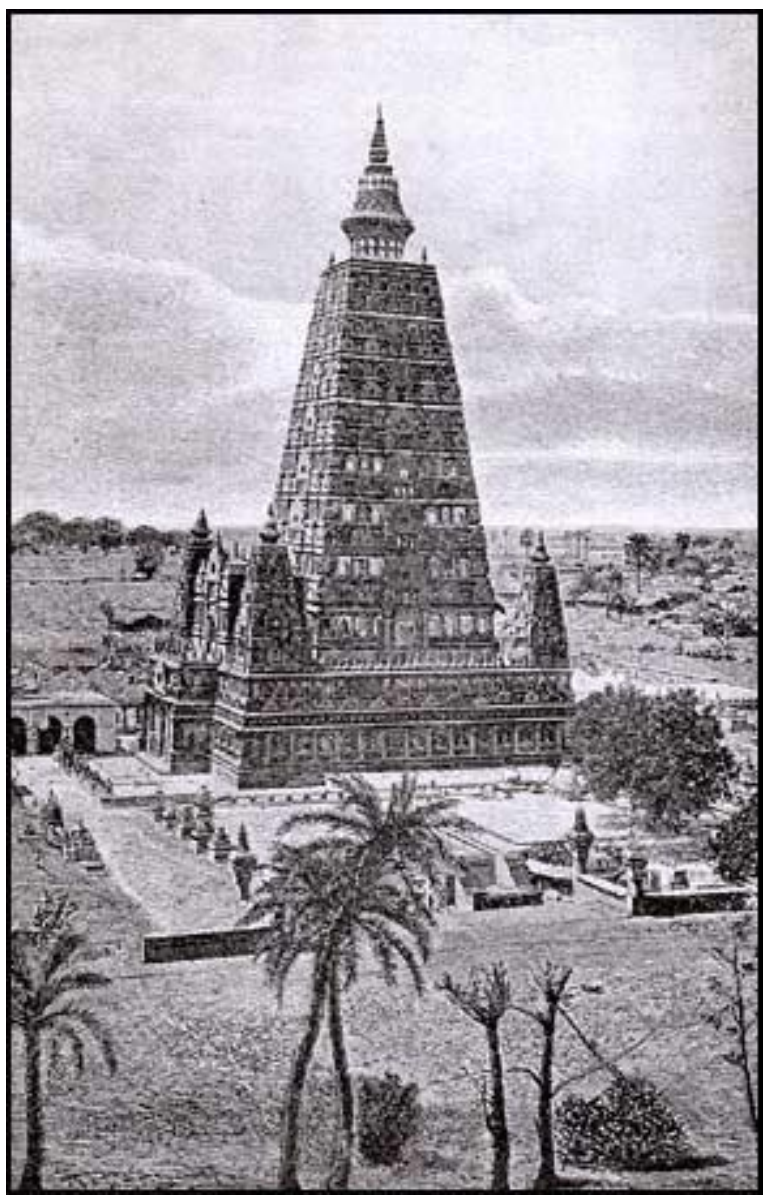

Figure 3: The view of the Mahabodhi temple after the

under restoration. This photograph was taken by Beglar,

Sanchi was discovered by Major General James Taylor in 1818. The place was visited later by Thomas Herbert Maddock, the political agent at Bhopal in 1822, Frederick Charles Maisey in 1849, Joseph Davey Cunningham, and Alexander Cunningham in 1851. The first account on Sanchi was by Captain Edward Fell in his work Description of an Ancient and Remarkable Monument near Bhilsa (1819) where there is a reference to two stupas on the hill site and that the second stupa didn't contain any sculpture or gateways. Cunningham and Maisey wanted to open the stupas systematically in order to find relic caskets. They adopted the method of digging a single vertical shaft down the exact centre of the stupa in order to minimize damage to the structure. The relic boxes and caskets were carried away by Cunningham and Maisey (Singh 2004). Later Cunningham 
elaborately wrote down the opening of the stupas. Restoration work at Sanchi began in 1881 under the supervision of Austin Mears and expenses were shared by imperial government and Shah Jahan Begum of Bhopal. In 1912 John Marshall renewed conservation works. The entire enclosed area overgrown with trees was cleared and then the excavation of the eastern and southern sides of the central plateau was undertaken. Temples, monasteries and stupas were found. Temples were repaired to a large extent. A move was also made by Bhopal Darbar to bring back the corporeal relics to Sanchi from the British Museum, taken away by Maisey and Cunningham. Around 1919, a discussion on this regard was held with Marshall. Almost three decades later the relics of Sariputra and Mahamogalana were brought back and enshrined on the Sanchi hill (Lahiri 2012). The transformation of Sanchi from a "disused ruin" and a site of "ravage and pilferage" to one of the best preserved "standing stupa complexes of antiquity" is certainly remarkable and is also a great achievement of Sir John Hubert Marshall (Guha Thakurta 2013).

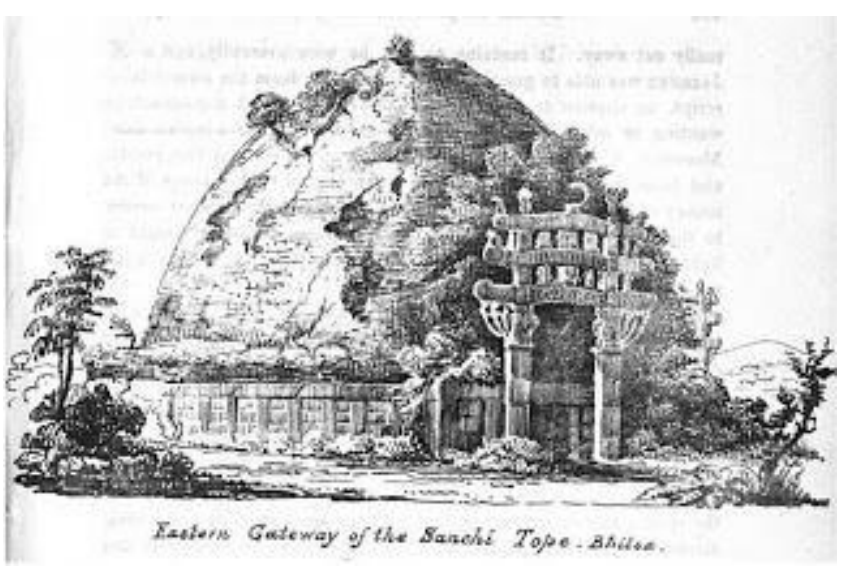

Figure 4: Eastern Gateway of Sanchi Stupa drawn by Captain

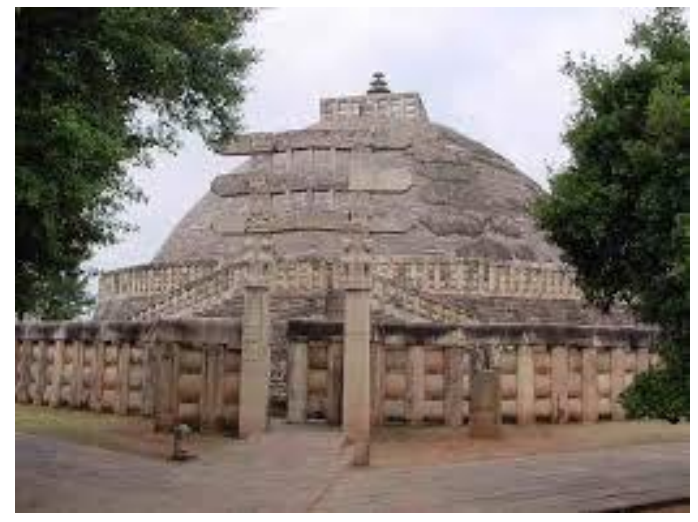

Figure 5: The eastern gateway of Sanchi of today.

William Murray in the 1830s.

Bharhut is located in Satna district, Madhya Pradesh. Bharhut Stupa was discovered by Cunningham in the month of November 1873 on his way to Nagpur when he could only ascertain portion of two gateways with the included quarter of the circular railing all in-situ, buried under a 'mound of rubbish from five to seven feet in height' (Cunningham 1879). In March 1874 both Cunningham and Beglar devoted time in excavating the entire railing of the stupa. Cunningham acknowledged the discovery of Prasenajit Pillar, of the famous Jetavana scene as a result of Beglar's consistent efforts. During this time, the smaller pieces of the eastern gateway were found. Cunningham's report on the discoveries was publicized internationally and this led to a demand from scholars to secure the sculptures for the museums in Calcutta and London. Finally they were transferred to the Indian Museum in Calcutta where they still adore the space. This transfer was criticized by some citing 'aroma of vandalism' but it was justified by Cunningham citing the" inveterate practice of the locals to carry away removable stones for building purposes" (Singh 2004). In April 1878 an Archaeological Gallery was opened in the Indian Museum where the remains of Bharhut were displayed. The Bharhut Stupa provides a typical example of ex-situ conservation practice. 


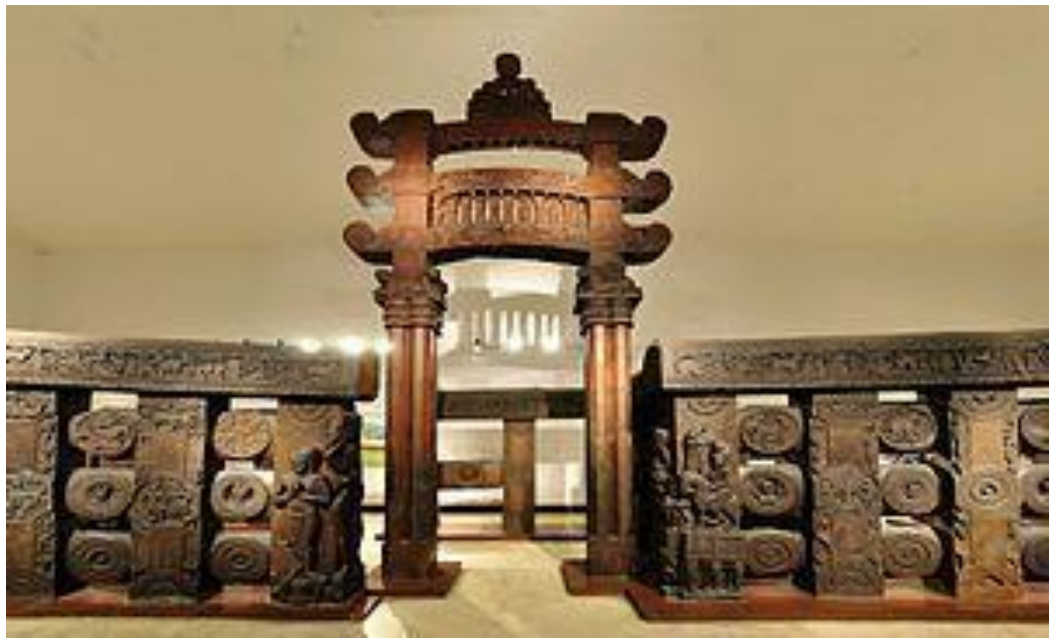

Figure 6: The eastern gateway and railing of the Bharhut Stupa adorning the space of Indian Museum, Kolkata.

The preservation of intangible heritage is another critical issue. The cultural traditions which have survived for generations from the time of our forefathers, and have been handed down to us obviously needs preservation, as this constitutes a pivotal part of our heritage. For example- the Ramlila, i.e. the traditional performance of the Ramayana through narration, recitation, song, and dialogue is performed each year during Dussehra. The most representative include mostly those of northern India like Ayodhya, Varanasi, Vrindavan in the state of Uttar Pradesh.

Recently, there have been attempts to revive the 'art of Urdu storytelling' known as 'Dastangoi', meaning 'to tell a story'. Dastans were actually epics which were often oral in nature and were recited or read aloud. Dastangoi died almost abruptly with the death of its last great practitioner Mir Baqar Ali in 1928. What were left behind were stories comprising about forty six volumes, each consisting of more than thousand pages. In 1980s the Urdu scholar Shamsur Rahman Faruqi started collecting the dastans. In 1998 he published the first volume of his tradition. With the efforts of Mahmood Farooqui to revive the tradition, the first modern Dastangoi performance was held at the auditorium of India International Centre, New Delhi on May 4, 2005 (Farooqui 2017).

\section{The Identity Question}

"Conversely, the identities produced by the interplay of organism, individual consciousness and social structure react upon the given social structure, maintaining it, modifying it, or even reshaping it. Societies have histories in the course of which specific identities emerge; these histories are, however, made by men with specific identities." (Berger and Luckmann 1967, p.173)

"As touchstones of history and identity, the things people preserve help them know who they are." (Lubar and Kendrick 2001, p.10)

At the outset it has to be made clear what the 'identity question' means in this context. It must be remembered that human beings generally are identified on the basis of their nationality in this world. This means that every single individual is a citizen of any one of the existing nations, and that each nation has its own identity established through both history and heritage. There occurs a dual interplay by which the nation and its citizen identify each other with its shared traditions. It is history which 'familiarizes a youth' with his own country, observed Rabindranath Tagore in his piece Bharatvarsher Itihas of 1902. In the context of heritage, "national culture has a meaning and it is political" (Hobsbawm 2013). It has also been contested that 'nation', 'nationality' and 'nationalism' is "notoriously difficult to define" (Anderson 1983). Moreover, it becomes 
increasingly important to examine the role of museums and artefacts, both of which contribute vastly towards understanding our history and heritage.

The word 'museum' originates from Greek 'museion', meaning 'Temple of the Muses'. It must be taken into account that the meaning of museum underwent substantial change from the Renaissance to the modern period. Initially, the galleries which stored the artefacts were known as museums but in the 18th century it became a public establishment. The term 'artefact' denotes 'a man-made object'. A noted historian comments -"The practices and scholarship of archaeology, traditions of historiography and claims about the past are all artefacts of history." (Guha 2015, p.1)

India's first museum was born in 1814, known as the Indian Museum, as a result of the decision of British archaeologists and scholars to store archaeological artefacts in India. It has been rightly pointed out that after India achieved independence, the government "made the museum a handmaiden of its nation building goal" and that the museum "answered the needs of a newly independent nation's prideful patriotism" (Lakshmi 2017). This is not only the case with India but also all other nations who were either colonies or were colonizers. The museum is the repository of vast knowledge of a nation's heritage where the artefacts adorning the museum space speak of a nation's history. Conversely, the museums do have 'reciprocity' or 'reciprocal value' of performing the role of constructing the formation of identities of the citizens and nation.

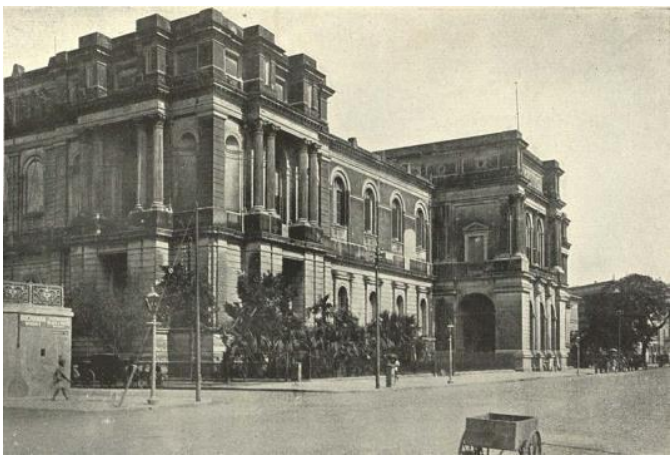

Figure 7: The Indian Museum of Calcutta, 1905. It was

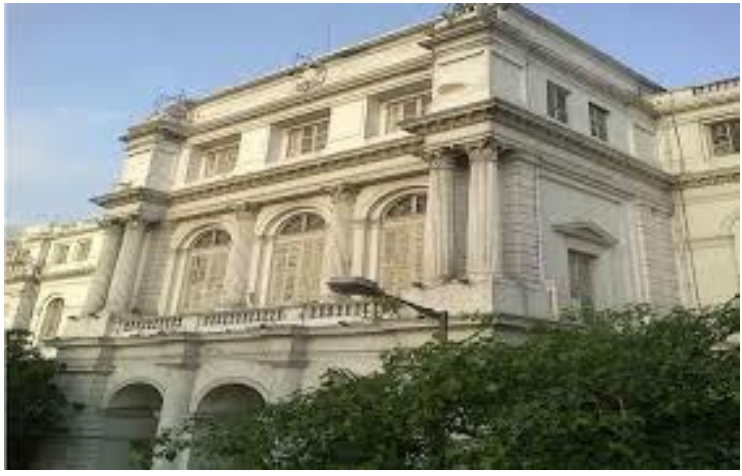

Figure 8: The Indian Museum as it stands today.

then better known as the Asiatic Society Museum.

In Mexico, the Union of Community Museums of Oaxaca is led by local indigenous communities as a tool to regain their collective identity and also to contribute to local development through promotion of tourism. Similarly, the National Handicrafts and Handloom Museum, New Delhi houses almost thirty three thousand artefacts. Artisans from all parts of the country perform and sell their product directly to the visitors. Rama Lakshmi aptly writes, "A museum that is born in and addresses a moment in transition will remain prepared and open for more changes in the future as well. Because even when the artefacts are fixed, the stories around them remain fluid, expanding and ever changing." (Lakshmi 2017, p. ix)

The museums do play the vital role of establishing 'symbiotic relationship' between them and the public. The 'democratization of societies' led to demands for knowledge and this influenced museum making. It has been rightly argued that museums became "important catalysts in stoking a certain nationalist cultural imagination among people" and that it became linked with "nationalism" on one hand and "tourism and entertainment" on other hand (Roychowdhury 2015). The National Museum, New Delhi, has very recently initiated an attempt to adapt to social media to engage with the public and recontextualize its collection (Parakala, 2019). 


\section{Conclusion}

It is very important to remember that all history writing is premised on the present (Guha Thakurta, 2004). Historians tend to look at a historical event in many ways which are both critical and complex in nature, which therefore results on the pouring of historical treatises on the same subject. Historical discourse in itself is "very complex" (Barthes 1984). The monuments or buildings or works of art that we read in history books did adorn the spaces in the real world. Some may have been victims of the cruelty of Time and some of 'other' Humans. These, which still survive do constitute our heritage, and that these heritages do have their own history. Heritage can give "prominence to, or submerge aspect of, its own history" (Thapar, 2018). The relationship between "what we see and what we know is never settled" (Berger 1972). With the new discoveries of objects, better known as artefacts and their residence in museums enhances our understanding of the human past. The visiting of the museum by a 'layman' is altogether a different question. The combination of all these things 'produces knowledge'- 'historical knowledge'. The artefacts, however, needs to be "interpreted in an appropriate way" (Pompa, 2002). Again from an all-round perspective, this combination also constructs 'identity'-the identity of a nation and also its citizens. A nation cannot be just a well-demarcated territory, the whole crux of its spirit and soul lies in its history and heritage collectively. The truth lies in the fact that "every man and nation needs certain knowledge of the past" and "according to his objects, powers, and necessities" (Nietzsche, 2005). The recognition of the importance of an "argumentative heritage" (Sen, 2005) and the formation of the past as "supreme spiritual heritage" (Burckhardt 1943) needs to be considered seriously in the wake of globalization and the fundamental problems facing the contemporary society. The way forward is by repositioning history as an "enabler to retrieve and recover horizontally an expansive, vertically a deeper, and a more inclusive past" (Bandyopadhyay and Sen, 2017). Invoking Carr, it might be said that not only history alone, but also heritage and archaeology do play a combined and shared role in continuing the "process of interaction" and "unending dialogue" between the past and the present and ultimately paving the way for the future.

\section{References}

Anderson, B. 1983, Imagined Communities: Reflections on the Origin and Spread of Nationalism (London, U.K: Verso).

Bandyopadhyay, S., and A.P. Sen 2017, Introduction. In: Religion and Modernity in India, edited by S. Bandyopadhyay and A.P. Sen (New Delhi, India: Oxford University Press), pp. 1-18.

Barthes, R. 1984, The Discourse of History. In: The Rustle of Language, translated by Richard Howard (New York, U.S: Hill and Wang), pp. 127-140.

Berger, J. 1972, Ways of Seeing (London, U.K: Penguin).

Berger, P.L., and T. Luckmann 1967, The Social Construction of Reality: A Treatise in the Sociology of Knowledge (New York, U.S: Anchor Books).

Bloch, M. 2017, The Historian's Craft (Delhi, India: Aakar Books).

Burckhardt, J. 1943, Reflections on History, translated by M.D. Hottinger and with an Introduction by G. Dietze (Indianapolis, U.S: Liberty Classics).

Chowdhury, I. 2017, Engaging with Public History. In: Museum Dialogue in India, edited by R. Lakshmi (New Delhi, India: Aryan Books International), pp. 15-20.

Collingwood, R.G. 1994, The Idea of History, edited with an Introduction by J. Dussen (New York, U.S: Oxford University Press).

Cunningham, A. 1879, The Stupa of Bharhut: A Buddhist Monument Ornamented with Numerous Sculptures Illustrative of Buddhist Legend and History in the Third Century B.C. (London, U.K: W.H. Allen and Co.)

Farooqui, M. 2017, Dastangoi: Revival of the Mughal Art of Storytelling. In: Museum Dialogue in India, edited by R. Lakshmi (New Delhi, India: Aryan Books International), pp. 39-44.

Geary, D. 2018, The Rebirth of Bodh Gaya: Buddhism and The Making of a World Heritage Site (New Delhi, India: Dev Publishers and Distributors). 
Guha, R. 1988, An Indian Historiography of India: A Nineteenth Century Agenda and Its Implications (Calcutta, India: K.P. Bagchi and Company).

Guha, S. 2015, Artefacts of History: Archaeology, Historiography and Indian Pasts (New Delhi, India: Sage).

Guha Thakurta, T. 2004, Monuments, Objects, Histories: Institutions of Art in Colonial and Postcolonial India (Ranikhet, India: Permanent Black).

Guha Thakurta, T. 2013, The Production and Reproduction of a Monument: The Many Lives of the Sanchi Stupa in South Asian Studies 29 (1) 77-109.

Hobsbawm, E. 2013, Fractured Times: Culture and Society in the Twentieth Century (London, U.K: Little, Brown).

Lahiri, N. 2012, Marshalling The Past: Ancient India and its Modern Histories (Ranikhet, India: Permanent Black).

Lakshmi, R. 2017, Introduction. In: Museum Dialogue in India, edited by R. Lakshmi (New Delhi, India: Aryan Books International), pp. viii-ix.

Lowenthal, D. 1998, The Heritage Crusade and the Spoils of History (Cambridge, U.K: Cambridge University Press).

Lubar, S., and K.M. Kendrick 2001, Legacies: Collecting America's History at the Smithsonian (Washington, U.S: Smithsonian Institution Press).

Murphey, M.G. 1973, Our Knowledge of the Historical Past (Indianapolis, U.S: Bobbs-Merrill).

Nietzsche, F. 2005, The Use and Abuse of History (New York, U.S: Cosimo Classics).

Parakala, V. 2019, Like, share, comment on history. The Hindu, 13 March.

Pompa L. 2002, Human Nature and Historical Knowledge (Cambridge, U.K: Cambridge University Press).

Roychowdhury, M. 2015, Displaying India's Heritage: Archaeology and the Museum Movement in Colonial India (Hyderabad, India: Orient Blackswan).

Said, E.W. 2001, Orientalism: Western Conceptions of the Orient (Gurgaon, India: Penguin Random House).

Selicato, F. 2016, The Concept of Heritage. In: Cultural Territorial Systems: Landscape and Cultural Heritage as a Key to Sustainable and Local Development in Eastern Europe edited by Francesco Rotondo, Francesco Selicato et.al. (Switzerland: Springer International Publishing), pp. 7-12.

Sen, A. 2005, The Argumentative Indian: Writings on Indian Culture, History and Identity (New Delhi, India: Penguin).

Singh, U. 2004, The Discovery of Ancient India: Early Archaeologists and the Beginnings of Archaeology (Ranikhet, India: Permanent Black).

Thapar, R. 2003, The Penguin History of Early India From The Origins To AD 1300 (Gurgaon, India: Penguin Random House).

Thapar, R. 2018, Indian Cultures As Heritage (New Delhi, India: Aleph).

Venkat, V. 2018, Historians Oppose Monuments Bill. The Hindu, 13 January. 